\title{
Maskinen i ånden
}

\author{
KJARTAN Fløgstad
}

\section{I}

I løbet af mine 30 år som forfatter har jeg pådraget mig et ry for at være tavs - og klog. Selv mener jeg, at dette både er ufortjent og uforståeligt, og at jeg snarere end tavs og klog er dumsmart og snakkesaglig, noget som jeg tydeligt har demonstreret ved at stille op her for at tale om værdier på filosofiske enemærker.

På den anden side bliver jeg ofte stum - stum af beundring - når jeg ser hvor dygtige - ikke mindst tilpasningsdygtige - mange af mine kolleger og generationsfæller er, når det drejer sig om at kunne levere lige præcis de sætninger, som til hver en tid er mest efterspurgte på meningsmarkedet.

Så dumsmart og stum er jeg alligevel ikke, at jeg kan undgå at udrykke en vis sorg, når jeg ser, at alle dagblade kappes om at være regeringsorganer, når hver eneste lederartikel er en slet skjult ansøgning til stillingen som ministersekretær, og når gamle kritiske intellektuelle pænt står og holder stigbøjlerne, når magthaverne skal svinge sig op på deres høje hest. Ja, skal vi tro toneangivende lokale propagandister for de herskende værdier, så er det at sætte forhindringer op for magtens vilde ridt $i$ sig selv præfascistisk og påfaldende tæt på apartheid-ideologien i Sydafrika.

Jeg holder på, at en ting er, at Muren i Berlin er faldet, ja jeg holder på at gå så langt som til at sige, at en ting er fandeme at Muren i Berlin er faldet. En anden ting er, at den samme mur ser ud til at være faldet lige i hovedet på en halv generation af gamle venstreintellektuelle, som fremdeles famler omkring med paradisiske forestillinger om det nye Europa uden at ane, at endevæggen for vores frihed ikke er Die Maner af Erich Honecker, men The Wall af Pink Floyd.
Når fundamentalkritikken forstummer, ikke bare fra talerstolene og $\mathrm{i}$ artikeldigtningen, men også fra romanfiktionerne, bliver digtningen om ikke kitsch, så $\mathrm{i}$ al fald edelkitsch, idet romanhelten ikke bliver til et elsdyr, men til en lektor i solnedgang, mens forfatterne går $\mathrm{i}$ frivilligt ideologisk Kierkegaardsasyl i dyb borgerlig muld, og digtningen bliver en slags jurassisk skrift, dyrket af unge og lovende dinosaurer. Da er tiden inde, og alt håb ude, for værdier, etik og moral.

Om sådanne og lignende spørgsmål har jeg flere gange udtalt mig både undrende og måske til og med sarkastisk. I den grad jeg har været med i den offentlige meningsudveksling, har det stort set handlet om at afgrænse mig i forhold til det tomt universalistiske og pompøst provinsielle ved de herskende vardier i den norske tænkemåde. Her har jeg måske ladet falde rigeligt med både hårde og tvetydige ord.

I forhold til den nyligt udnævnte værdikommission føler jeg, at jeg må tænke, og eventuelt afgrænse $i$ en helt anden, ja sandsynligvis modsat retning. For selv om det er en ærkenorsk kommission, repræsenterer den ikke entydigt den norske tænkemåde. Af flere grunde.

Kommissionen stammer ikke fra "Netværket“ af kejserlige intellektuelle i tyngdefeltet omkring Det Norske Arbejderparti/Højres markedsstyrede moderniseringsbestræbelser. Socialt repræsenterer den ikke bare en snæver elite med basis i den øvre middelklasse.

Kommissionen er heller ikke så kulturradikal, at det gør noget. Den er udnævnt af et præstestyre, og bærer præg af det. Fra Hollywood ved både regeringen og vi andre desuden, at selv om kunsten er værdifuld, er den alligevel umoralsk. Skurken afslø- 
rer sig ved at have abstrakt ekspressionisme på væggene. Det æstetiske subjekt er ikke et moralsk subjekt. Tværtimod. I den grad kunsten kommer til orde i kommissionen, er det i munden på kunstnere, der har udmærket sig som populære, for ikke at sige populistiske underholdere. Således stadfæster sammensætningen af kommissionen på en træffende måde kunstens trivialisering, men først og fremmest kunstens samfundsmæssige rolletab. Og det kan vi jo sige er en værdi i sig selv. (Selv har jeg tidligere peget på, at kunstens rette plads i samfund af vores slags er på Vedø, længst ude i Røst-øhavet i Lofoten, hvor Luciano Fabros storartede skulptur „Il Nido" troner på en mennesketom holm under et svævende, skrigende fjeld - af fugle - som driver tilskueren bort).

Selvsagt er dette en tvetydig marginalisering af kunstens værdi. Samtidig med at fagpolitikken i Stortinget og forvaltningen ikke længere går til kunsten for at finde ny erkendelse, er det også sådan, at store og toneangivende ungdomsgrupper ser kunsten som den eneste vej til transcendens og værdiskabelse.

Det drejer sig om kunsten som senmoderne ideologi. Eller rettere sagt: om kunsten som ideologien for det senmoderne. Mod dette felt, som jeg kun tøvende kalder avantgardistisk, har regeringens Værdikommission ikke engang udsendt følere. Det isolerer den, socialt som ideologisk. Samtidig giver det kommissionen en slags patetisk styrke. Når jeg tænker på, at en hel kommission af stovte bønder, landsholdstrænere, sognepræster, sygehjælpere og politifolk fra hele landet, under fagligt opsyn af departementschef Fred Olav Sørensen, $i$ årevis fremover skal bedrive værdimobilisering på vores vegne, bliver jeg i alle tilfælde grebet og varm i sindet, omtrent på samme måde som når jeg hører en andægtig lutheransk salme, eller en ny schlager, eller ser langrendsløberen Erling Jevne vinde sølv til OL, eller rejser gennem Ryfylke med hurtigbåd, eller ser norske diplomater føre stridende parter til forhandlingsbordet, fra Mellemøsten til Mellemamerika.

Og den som tror, at dette er ironi, må finde den i sin egen sorte sjæl.

\section{II}

Og den som tror, at der kan komme noget gavnligt ud af værdimandatet til regeringen, må lade en sort tanke formørke sit lyse sind.

Også politisk lever vi i dag i en religiøs tid. Hvor politisk glød er blevet til litterær aske, er det Kierkegaardsvogterne, som ligger på knæ og blæser til gløderne. På samme tid som Kristeligt Folkeparti flytter ind $\mathrm{i}$ regeringskontorerne, bliver markedstænkningen flyttet ud af politiken og får teologisk status. Kritik af markedsøkonomien er således blasfemisk. Gud er god, men vi arme mennesker har ikke altid nåden til at se det. Sådan er det også med markedet. Det er godt, selv om det ser skidt ud, på storbyhimlen og i Indonesien. Du skal ikke have andre guder end mig. Men hvordan tro på den frie konkurrence som gud, når konkurrenceideologien har udryddet alle konkurrenter? Når der ikke findes politiske forskelle i Stortinget, men større og større forskel på folk, hvad er da forskellen?

Da er forskellen den, at de sociale følger af markedsøkonomien med stor konsekvens undergraver netop det værdigrundlag, markedsøkonomien påberåber sig. Jo mere markedsteologerne prædiker faste værdier, jo hurtigere får markedspolitikken disse værdier til at bryde sammen. Markedstilhængerne drømte om ti tv-kanaler $i$ stedet for den ene statslige. $\mathrm{Nu}$ har vi fảet dem. Og endda ti til. Alligevel er der ikke engang fodbold mere på nogen af dem. Regeringsaviser og opposition skifter kommentatorer uden at nogen bemærker forskellen. I fraværet af kritik danner massemedier og statsmagt et virtuelt partiapparat, som mere og mere får samme facon som tv-apparatet, og som udøver enevælde gennem en form for televiseret bonapartisme, hvor presse og massemedier hverken er den fjerde statsmagt eller den fjerde nattevagt, men den fjerde nattemagt $i$ et afindustrialiseret, afideologiseret samfund, hvor stadig flere får læse- og skriveproblemer i Gronattens mørke.

Grodagen var kendt som en ekstra feriedag. Gronatten er det nationale fornavn på politikkens afideologisering. I denne Gronats mørke er alle katte grå, og Carl I. Hagen er mørkets ukronede fyrste. 
Under den profitøkonomiske okkupation af politikken er stortingspartierne et bredt sammensat administrationsråd, hvor de skiftende statsministre har samme betydning og lige så stor magt som amtmand Christensen under en anden besættelse. Økonomien er hest, politikken kærre, og politikeren en kusk som sidder bagvendt med ryggen mod hesten og styrer kærren.

I forhold til denne køretur har storkoalitionen Det Norske Arbejderparti/Højre en lykkelig medvind. Her kan vi se Jess Stoltenbergs smilende ansigt for os som ikon. Værdikommissionen er udtryk for en ulykkelig bevidsthed om det markedsstyrede moderniseringsprojekt. Det er noget af det bedste, som kan siges om den. Men for at få os på rette vej, vil den rose hesten og formane os som sidder i kærren.

\section{III}

Værdikommissionen repræsenterer hverken stærke kapitalkræfter eller toneangivende intellektuelle netværk. Den er heller ikke knyttet til den kunstneriske avantgarde. Den har tværtimod sit tyngdepunkt i de klassiske norske modkulturer. Først og fremmest er personkonstellationen præget af forskellige former for kristelighed. Dernæst har den et stærkt præg af udkant. Det er virkelig ,,anderledeslandet“ eller „the centrality of margins“ som hos Jorge Luis Borges. Velvilligt tolket er kommissionen ikke modernistisk, men har fået mandat til at lede efter andre moderne værdier end de markedsstyrede.

„Familien er samfundets grundenhed“ slår den kongelige resolution utvetydigt fast, tilsyneladende helt $\mathrm{i}$ tråd med kristelige værdier og bygdenorske fællesskabsvaner. Her ved vi alligevel, at når det gælder om at leve op til denne moralske familiemaksime i praktisk politik, er lederskabet i Oslo Arbejderparti et uopnåeligt forbillede.

Samtidig med at resolutionsteksten på denne måde påkalder den politiske kernefamilie som hævdvunden værdi, kan vi fornemme, både ud fra det idéhistoriske tyngdepunkt i Kommissionens styringsgruppe, og i måden hvorpå mandatet er be- grundet, at den søger i retning af et nyt og udvidet, ja socialt altomfattende familiebegreb.

Som vi kunne vente, er det ikke den mafiøse, katolske storfamilie som skal føre de kristelige familieværdier fra regeringen ud i samfundslivet. Den hellige, mafiøse familie er ganske vist temmelig tæt og varm, men så varm, at det ofte bliver hedt om ørerne på de, der bryder med familieværdierne. Den styrker familiebåndene ved at slække på de sociale bånd. I stedet for den katolske storfamilie fornemmer vi i Kommissionens mandat snarere et shintoistisk eller konfusiansk familiebegreb, som på japansk eller koreansk vis spreder familieværdierne til alle kanter af samfundslivet, sådan at familien bliver vennekredsen, arbejdskollegerne, fodboldholdet, forsikringsselskabet med den administrerende direktør i spidsen som allestedsnærværende storfamiliefar.

Ikke familien som proletarisk kampenhed, som det hed i halvfjerdserne, men samfundet som børsnoteret storfamiliefællesskab.

Ikke alene er vi i samme båd. Vi er også i familie. Hvis vi er heldige, står vores efterkommere på hemmelige medlemslister i ungdomsorganisationen til et af de statsbærende partier. Så kan de unge slægter høste.

\section{IV}

I selve mandatet til Værdikommissionen er substantivet politik ikke nævnt med et ord. Adjektivet politisk er anvendt en eneste gang i en sætning, hvor Regeringen beder Kommissionen om at drøfte forholdet mellem politiske styringsorganer på den ene side, og det enkelte individ, familien, civilsamfundet og „næringslivet“ (det vil sige kapitalejerne) på den anden. Den værdimæssige og samfundsetiske mobilisering skal med andre ord først og fremmest dreje sig om grenserne for politik, afgrænsningerne mellem magtpolitikken og moralen, ikke om politikkens indhold. At der samtidig med Værdikommissionen er udnævnt en Magtkommission, støtter denne tolkning af Værdikommissionen som en politisk afmagtskommission.

Og set fra Værdikommissionens opgavestillers perspektiv er det måske ganske godt. Samtidig med at kommissionen blev udnævnt, blev flertallet $\mathrm{i}$ det 
nationale sikkerhedsråd i Washington udnævnt til Det internationale Samfund, og den kristelige udenrigsminister kunne energisk give moralsk og materiel støtte til USAs planer om angrebskrig i Den persiske Bugt. Da kunne det vel være på sin plads at have afgrænset politikken som et felt, hvor moralsk værdimobilisering ikke kommer i vejen for militær styrkemobilisering.

Men også på andre felter er etikken udtømt, og moralen har ophævet sig selv. Nyliberalismen har som bekendt gjort den geniale opdagelse, at de rige ikke vil arbejde, hvis de tjener for lidt, mens de fattige ikke vil arbejde, hvis de tjener for godt. I mandatet til Værdikommissionen bliver der talt længe og godt om skole, kirke og frivillige organisationer. Om arbejderbevægelsen derimod, ikke et ord. I oplægget til kommissionen er den industrielle erfaring udvisket, og dermed de solidariske værdier i arbejderkollektivet. Efter arbejderklassen er det parentes slut. Således er også alle tilløb til dialektik og materialisme fraværende. Her er der tale om den agte samtale, om positive fællesskabsværdier og sund værdiformidling. Mandatet til Værdikommissionen er gennemsyret af idealisme og fornægtelse af sociale modsætninger og spændinger i samfundet.

Men misfornøjelsen er moder til fremgangen, som Vinje siger. Og ser vi nærmere efter, er en række af de positive værdier kommissionen vil holde fast ved, skabt gennem negationen af negationen af disse værdier. I februar i år kunne vi fejre Iso året for udgivelsen af det mest værdifulde politiske skrift i moderne tid. Det kommunistiske manifest som blev offentliggjort i London i februar 1848 , og den kommunistiske udfordring var en hovedårsag til, at arbejderklassen i det kapitalistiske Vesten formåede at tvinge magthaverne til et klasseforlig, som fik værdifulde følger for begge parter.

Sådan set er det derfor centralkomitéen i det sovjetiske kommunistparti, der er vores (og ikke nødvendigvis deres) vigtigste værdikommission gennem hele det korte århundrede fra 1917 til 1989. Tvangskollektivisering og betonsocialisme i Øst forte til en kapitalisme med et menneskeligt ansigt $i$ Vest.
V

I dag er Verdensbanken, Valutafonden og Den socialistiske Internationale i skøn forening enige om, at det er den økonomiske udvikling, der fremtvinger nedskæringer i udgifter til offentlige værdier som sundhedsvæsen, socialhjælp, kultur, kunst og uddannelse. Globalisering fremtvinger nedbrydning af velfærdsstaten, som det hedder.

Men i stedet for at se på globaliseringen som en objektiv økonomisk naturlov, kan det være, at truslen mod velfærdsstaten i stedet er en følge af ændringer i styrkeforholdet i klassekampen, til fordel for kapitalen, både nationalt og internationalt.

Men med den økonomiske globalisering følger også en kulturel logik, som Slavoj Žižek har kaldt for multikulturalisme. For multikulturalismen har alle lokale kulturer samme værdi, som de indfødte kulturer havde for de gamle koloniherrer. Efter den imperiale kolonisering kom den globale selvkolonisering. Med overbevisende eurocentrisk distance ser multikulturalismen på lokale kulturer på nogenlunde samme måde, som pladeindustrien ser på ,etnisk" musik.

Samtidig fornægter multikulturalismen at have rødder i en særegen lokal kultur. Erling Fossen peger $i$ et interview på, at han er mere i slægt med en græsk bonde end med en nordmand af bondestand. Fossen taler vel og mærke ikke græsk, men har besøgt græske badesteder som turist. Sådan forsøger den multikulturalistiske elite at løfte sig op ved håret og løsrive sig fra al kulturel loyalitet. Alle lokale kulturer får samme status, bortset fra den man selv kommer fra. Den er mere plagsom, rå, bondsk og truende end de andre. $\mathrm{Og}$ den råhed er den fineste værdi sådan en som jeg kan udtrykke.

De multinationale selskaber har i dag samme holdning til den lokale arbejdskraft i Norge, Frankrig og USA, som koloniherrerne havde til de indfødte i Brasilien og på Guldkysten. Den multinationale kultur koloniserer i dag ikke bare andre lande, men også sine egne. Kolonimagten er ikke længere en nationalstat, men et multinationalt selskab, som gør alle lande til økonomiske kolonier.

Som SlavojŽižek siger: I fremtiden vil vi ikke blot gå med Banana Republic skjorter, vi vil alle som en 
bo i Banana Republics (eller i Mangana Kingdoms, sådan som hvor jeg voksede op). Og hvor det ikke er bananer, men et gyldent håndtryk og repræsentationskonto med guldkort, der er det materielle værdigrundlag som sikrer god moral.

\section{$V I$}

Til sidst, eller næstsidst, må det siges, at den moralske og politiske reaktion på multikulturalismen kan vise sig på meget ubehagelige måder. Højrepopulismen har været på fremmarch, særligt hvor multikulturalismens liberale programerklæringer mest hovmodigt benægter de sociale skadevirkninger af markedspolitikken. Arbejdsløshed, narkoproblemer, kriminalitet, storbyvolden, ulandsfattigdommen er uafviselige symptomer på den sociale logik i senkapitalismen.

Gennem den socialistiske verdensbevægelse, både i kommunistisk og socialistisk udgave, blev de fattige, ejendomsløse og udstødte i almuen og underklassen moderniseret til arbejderklasse, til et stolt og selvbevidst proletariat. Som oprørsk, revolutionært subjekt blev arbejderklassen del af, for ikke at sige den stærkeste bærer af det moderne projekt. Dette er uden sammenligning den vigtigste værdi ved moderniteten.

En af følgerne af at klassekampen nu er imploderet, både nationalt og internationalt, er at fra at være et moderne, politisk proletariat, prøver magthaverne på ny at støde underklassen ud af moderniteten og omdanne den til en postmoderne, plebejisk, rå og forblindet almue, som famler rundt $i$ et massemedialt ideologisk mørke, $i$ den sorteste politiske Gronat med Hagen som mørkets fyrste.

FRP er vores største eller vores næststørste arbejderparti. Arbejderpartiet er vores største eller vores næststørste Fremskridtsparti. Værditabet, som ligger i denne reduktion, kan ikke erstattes med etikken, men ved at genåbne det politiske felt, ved at opfinde politikken på ny, det vil sige ved at generobre vores erne til at forestille os et bedre samfund.

\section{III}

For hundrede år siden, op mod forrige århundredskifte, mente videnskaben, at naturlovene stort set var udforsket til ende. Alt stemte, hvis man så bort fra nogle små og ubetydelige afvigelser inden for fysik og mekanik, som ingen tog helt alvorligt.

I disse små og ubetydelige afvigelser lå hele det 20. århundrede i kim: relativitetsteorien, kvantemekanikken, atombomben, elektronikken.

I dag, før et nyt århundredskifte, siger de førende tænkere, at historien er slut, at kapitalismens økonomiske love gælder uindskrænket. Alt stemmer, bortset fra værditabet, forureningen af luft og vand, den demografiske katastrofe i det gamle Sovjetunionen, som nærmer sig stalinistisk niveau. Sådanne småting.

Det skræmmende ved dette samfundsmaskineri er ikke, at det bliver styret af onde og profithungrende umennesker. Som det er blevet sagt: Det skræmmende ved senkapitalismen er ikke ånden i maskinen, men maskinen $\mathrm{i}$ ånden.

Men også denne maskine trænger til eftersyn for at kunne virke. Walter Benjamin skrev, at holdninger er for samfundslivets vældige apparat det samme som olie er for maskiner: man stiller sig ikke op foran maskinen og hælder olie på den.

I det rige Olienorge er det måske netop det vi gør. Olierigdommen har givet os råd til at lade en hel kommission stå $\mathrm{i}$ årevis foran samfundsmaskineriet og hælde olie på dækslet. Men i al fald ved vi, som har arbejdet $\mathrm{i}$ industrien, at skal vi fả maskinen til at køre - eller til at gå i stå - må vi kende smørekortet på forhånd, og føre fedtsprøjte, oliekande og holdninger ind mod de små og ubetydelige nippler og smørepunkter, som fører lige ind til ånden i maskinen.

På dansk ved Mads Rosendahl Thomsen 